\title{
BOLDOGSÁGMÉRÉS AZ ISKOLÁBAN
}

\section{VARGHA ANDRÁS ${ }^{1,2}$ - TÖRÖK REGINA ${ }^{1}$ - DIÓSI KAROLA ${ }^{1,2}-$ OLÁH ATTILA ${ }^{2}$}

\author{
${ }^{1}$ Károli Gáspár Református Egyetem \\ ${ }^{2}$ Eötvös Loránd Tudományegyetem \\ E-mail: vargha.andras@kre.hu
}

Beérkezett: 2019. szeptember 11. - Elfogadva: 2019. október 14.

\begin{abstract}
Felnôttek esetén a szubjektív jóllét és a mentális egészség mérésére számos kérdốv áll rendelkezésre, de gyermekek esetén ilyen teszteknek szükében vagyunk. A szubjektív jóllét mérése iskolai környezetben is fontos, magyar nyelvú teszt azonban az általános iskolai korosztály számára nem áll rendelkezésre. A jelen tanulmány célja Ivens (2007) e célra kialakitott tesztjének magyarra adaptálása (IGYBH), illetve egy öt pilléren (jóllét, savoring, alkotó-végrehajtó hatékonyság, önreguláció, reziliencia) nyugvó felnött magyar mentális egészség teszt, a MET 10-14 éves korosztályra adaptálása. Az elvégzett pszichometriai elemzések igazolták mindkét teszt szerkezeti megfelelöségét 10 éves kor fölött, és pozitív eredményeket kaptunk a két teszt validitásával kapcsolatban is. Érdekes eredményként adódott, hogy magasabb osztályokban a tanulók szubjektívjóllét-szintje alacsonyabb.
\end{abstract}

Kulcsszavak: boldogságmérés, szubjektív jóllét, mentális egészség, IGYBH, METGy

\section{BEVEZETÉS}

A boldog ember egészséges, és gyorsabban gyógyul (Veenhoven, 2008), tovább él (Diener és Chan, 2011), hatékonyabban dolgozik (Zelenski, Murphy és Jenkins, 2008), empatikus és segítôkész (Hauser, Preston és Stansfield, 2014), illetve kreatív (Myers, 2000). A köznapi boldogság - tudományos terminussal szubjektív jóllét (vö. Ivens, 2007) - a globális jóllét ${ }^{1}$ mentális állapota. Boldog az az ember, aki humán természetének minden aspektusában, vagyis biológiai, pszichológiai, szociális és spi-

1 A globális jelzố itt nem arra utal, hogy valamilyen világméretû́ jelentôséggel bíró skáláról van szó, hanem arra, hogy a skála egy olyan általános jóllétet mér, mely egyaránt magában foglalja a biológiai, a pszichológiai, a társas és a spirituális jóllétet. 
rituális szinten egyaránt jól múködik, miközben jól is érzi magát a bőrében (Oláh és Kapitány-Fövény, 2012).

Felnôttek esetén a szubjektív jóllét és a mentális egészség mérésére számos teszt áll rendelkezésre (lásd pl. Diener, Emmons, Larsen és Griffin, 1985; Szabó, 2019). Szerkesztettek ilyen tesztet 14-18 éves serdülôk számára is (pl. Láng, 2019), ennél fiatalabb gyermekek esetén azonban a paletta korántsem ilyen gazdag. Mindössze Ivens (2007) iskolai környezetben alkalmazható gyerekboldogság kérdőívét (School Children's Happiness Inventory, SCHI) említhetjük. De miért is fontos a szubjektív jóllét és a mentális egészség mérése az iskolában? Az evidens morális okon túl említsünk meg két további indokot.

1. A mentális zavarokkal rendelkezô tanulók iskolai teljesítményükben is gyengébbek, továbbá viselkedésükkel gyakran osztálytársaikra is negatívan hatnak (Roeser, Van der Wolf és Strobel, 2001).

2. A szubjektív jóllét magas szintjével jellemezhetô tanulók többnyire pozitív, optimista, bizalomteli állapotban vannak, s ezáltal nyitottak új ismeretek befogadására és a flow átélésére iskolai környezetben (Fredrickson és Branigan, 2005; Reinhardt, 2009).

Ezen okok fontosságát felismerve vágtunk bele olyan magyar nyelvú pszichológiai tesztek kialakításába, amelyek alkalmasak a szubjektív jóllét és a mentális egészség mérésére iskolai környezetben. A szubjektív jóllét mérésére Ivens (2007) angol nyelvú Iskolai Gyerekboldogság Kérdôívét (IGYBK) adaptáltuk magyar nyelvre, a mentális egészség mérésére pedig a felnôtt magyar populációra kialakítás alatt álló Mentális Egészség Tesztet (MET, vö. Oláh, Nagy, Magyaródi, Török és Vargha, 2018; Vargha, Diósi, Pásztor, Ódor és Csengôdi, 2018) igazítottuk a 10-14 éves korosztályra. Jelen tanulmányunk e vizsgálatokkal kapcsolatos munkánkat és azok eredményeit ismerteti.

\section{Az Ivens-féle Iskolai Gyerekboldogság Kérdối (IGYBK)}

A 8-15 éves gyermekek iskolai szubjektív jóllétének mérésére kialakított IGYBK 30 tételbôl áll, és a vizsgált személynek 4-fokú Likert-skálán kell megítélnie, hogy az adott állítás mennyire igaz rá (1: nagyon nem jellemzô, 4: nagyon jellemzô). A kérdôív állításai mind arról szólnak, hogy a kitöltô az elmúlt héten hogyan érezte magát az iskolában (pl. Tele voltam energiával; Ideges voltam; Akartam iskolába jönni; Rosszkedvú voltam stb.). Az IGYBK tesztszerkesztési koncepciója követi azt az elvet, miszerint a szubjektív jóllétnek van egy pozitív és egy negatív összetevôje (Diener, 1984). Ez okból a tételek fele pozitív (pl. Tele voltam energiával), fele pedig negatív (pl. Rosszkedvú voltam) megfogalmazású. Az IGYBK pozitív (IGYBpoz) és negatív (IGYBneg) alskálája a pozitív, illetve a negatív megfogalmazású tételek pontértékeinek összegeként adódik, az IGYB összpontszámot pedig az összes tétel pontértékének összegeként kapjuk, miután a negatív tételek pontértékét átfordítottuk.

A mérôeszköz létrehozásának egyik indoka egy olyan skála hiánya volt, melynek segítségével azonosítani lehet az iskolában bántalmazott (angolul bullied) gyerekeket. Ezt tekintették az IGYBK egyik kritérium validitásának is, és ennek Ivens (2007) konkurens prediktív vizsgálata szerint az IGYBK meg is felelt. Hierarchikus regresszió- 
elemzéssel keresztmetszeti mintán ugyanis azt kapták, hogy az IGYB egy kombinált bántalmazásskála varianciájának 11\%-át magyarázza. Egy másik vizsgálatban (Ivens, 2007, 2. vizsgálat) egy 77 fớs minta segítségével azt is sikerült kimutatni, hogy az IGYB az önbecsüléssel $(r=0,49)$ és a PANAS-C (Laurent és mtsai, 1999) érzelem (Affect) alskálájával $(\mathrm{r}=0,71)$ közepesen, illetve kiemelkedően erôs pozitív, a depresszióval pedig közepesen erôs negatív $(r=-0,55)$ kapcsolatban van, az elôzetes elvárásoknak megfelelöen.

\section{A Mentális Egészség Teszt (MET)}

A pozitív pszichológia egyik küldetése és feladata az, hogy egy elméletileg megalapozott és mérôeszközként tekintve is érvényes tesztet dolgozzon ki a mentális egészség mérésére. Magyar populációban Oláh és mtsai (2018) nevéhez füződik egy új mentális egészséget méró kérdőív, a Mentális Egészség Teszt (MET) kidolgozása. A mentális egészség magában foglalja azt a készséget, amellyel az egyén megéli és megôrzi pozitivitását. Ehhez tartozik a hatékony megküzdés képessége, a savoringre való hajlam, valamint a reziliencia és a dinamikus önszabályozás jelenléte. Ebból fakadóan a mentális egészségnek az az 5 pillére, amelynek mérésére a MET-et kidolgozták:

1. Globális jóllét: az érzelmi, pszichológiai, szociális és spirituális téren egyaránt megtapasztalt magas szintú jóllét (Oláh és Kapitány-Fövény, 2012).

2. Savoring: a pozitív élmények, az öröm érzésének átélése, tudatosítása és feldolgozása (Szondy, Martos, Szabó-Bartha, Pünkösty, 2014).

3. Alkotó-végrehajtó individuális és szociális hatékonyság: az a kompetencia, amelylyel az egyén képes a nehezített alkalmazkodási helyzet körülményeit megváltoztatni, igényeinek megfelelően eljutni a választott céljaihoz, továbbá akár az önmaga, akár a fizikai vagy szociális környezet megváltoztatására szôtt terveit szándékainak megfelelôen megvalósítani (Oláh, 2005).

4. Önreguláció: a figyelem és a tudati múködés feletti kontroll, célelérésben perzisztencia, az érzelmi állapotok kontrollálása, az önszabályozás képessége (Oláh, 2005).

5. Reziliencia: lelki rugalmasság, pszichológiai ellenálló képesség (Block és Kremen, 1996; Smith és mtsai, 2008). Azon tényezôket foglalja magában, amelyek elôsegítik a stresszes helyzetekhez történô sikeres alkalmazkodást, a lelki gödrökbôl, megrázkódtatásokból való gyors és hatékony felépülést (Campbell-Sills és Stein, 2007; Connor és Davidson, 2003; Southwick, Bonanno, Masten, Panter-Brick és Yehuda, 2014; Southwick és Charney, 2018).

Az erre az 5 pillérre kialakított 5 skálával a Mentális Egészség Teszt konstruktuma itemanalízis és konfirmatív faktoranalízis (CFA) által igazoltan jó modellt alkot a felnôtt magyar populációban (Oláh és mtsai, 2018). A modell ötvözi a flourishing (virágzás) fogalmát azokkal a képességekkel (megküzdés, savoring, reziliencia, dina- 
mikus önszabályozás, pszichológiai immunitás), amelyek szerepet játszanak a mentális egészség megörzésében.

Vargha és munkatársai (2018) vizsgálták a Mentális Egészség Teszt skáláinak kapcsolatát szociodemográfiai változókkal. Az ordinális jellegú szociodemográfiai változókkal Spearman-féle rangkorrelációkat számoltak, nominális változók (nem és családi állapot) esetén pedig csoportátlagokat hasonlítottak össze. Nagy mintán $(\mathrm{N}=554)$ végzett elemzéseik főbb eredményei nevezetesen: (1) A kor pozitívan korrelál az önregulációval és a rezilienciával. (2) Az iskolázottság pozitívan korrelál a jólléttel, az alkotó-végrehajtó hatékonysággal és a rezilienciával. (3) A gyermekek száma pozitívan korrelál a jólléttel, a rezilienciával és az önregulációval. (4) Az anyagi helyzet pozitívan korrelál a jólléttel és az alkotó-végrehajtó hatékonysággal. (5) A férfiak jobbak az önregulációban, viszont alacsonyabb a savoringszintjük. (6) A házasságban élôk magasabb pontszámot értek el az egyedülállókkal összehasonlítva a jóllét és a reziliencia tekintetében, illetve magasabb pontszámot értek el a párkapcsolatban élókkel összehasonlítva az önreguláció és a reziliencia tekintetében. A párkapcsolatban élók az egyedülállókkal összehasonlítva magasabb jóllétszintet mutattak.

\section{MÓDSZER}

\section{Résztvevók}

Az érvényes vizsgálati mintát ${ }^{2} 1415$ 3-8. osztályos tanuló képezte az ország 28 különbözô általános iskolájából, Zalától Békésig. Az iskolákban az volt a közös, hogy mindegyikben folyt boldogságóra ${ }^{3}$ legalább egy osztályban. Az ilyen osztályokba járók száma 1172 volt (579 fiú és 590 lány, 3 gyerek neme nem volt megadva), 243-an (111 fiú és 131 lány, 1 gyerek neme nem volt megadva) pedig olyan osztályokba jártak, amelyek nem vettek részt a boldogságóra-programban. A vizsgálatokra 2018-2019-ben került sor többnyire a boldogságórákon vagy osztályfơnöki órákon, ritkán egyéb órák (pl. énekóra) alatt. A kérdôíveket a Jobb Veled a Világ Alapítvány közremúködésével ${ }^{4}$ e-mailben küldtük el az iskoláknak, akik helyben kinyomtatták, a vizsgálatokat elvégezték, és a kitöltött kérdôíveket postán visszaküldték.

\section{Etikai vonatkozások}

A vizsgálat a KRE Pszichológiai Intézetének Kutatásetikai Bizottsága engedélyével zajlott (IKEB 177/2018/P). 


\section{Méröeszközök}

\section{Az Ivens-féle Iskolai Gyerekboldogság Kérdối magyar változata (IGYBKH)}

A 30 tételes eredeti angol kérdő́ivet (lásd Ivens, 2007, Appendix) a jelen cikk elsố szerzôje fordította le magyarra két kompetens nyelvi lektor ${ }^{5}$ által ellenôrzötten (lásd cikkünk mellékletét). A 30 tétel mindegyikénél a vizsgált személynek 4-fokú Likert-skálán kell eldöntenie, hogy az adott állítás mennyire igaz rá: 1 - „nagyon nem jellemzô”, 4 - „nagyon jellemzô”. A kérdőív 15. (I enjoyed myself) és 21. (I felt good) tételét egyaránt a „Jól éreztem magam” állítással fordítottuk, egyrészt a lényegében azonos jelentés miatt, másrészt azért, hogy legyen a 30 tételes kérdőívben olyan kontroll állítás, melynek segítségével a komolytalan vagy túlságosan bizonytalan és ezért értékelhetetlen kitöltôk kiszúrhetôk. Vizsgált személyeink közül a két azonos 4-fokozatú állításra 28-an 2 egységgel, 20-an 3 egységgel eltérô értékú választ adtak, vagyis a kérdốíven az egymástól mindössze ötállításnyi távolságra elhelyezkedó 16. és 21. kijelentésre 48-an ellenkezô irányú választ jelöltek be. E személyek adatait természetesen kihagytuk az elemzésekból - a fentebb megadott érvényes mintába nem is számítottuk be ôket, ugyanúgy, ahogy azokat se, akik a 30 közül legalább öt tételre nem adtak érvényes választ $(\mathrm{N}=26$ fö $)$.

Az érvénytelen jegyzôkönyvek elhagyása után a 16. és a 21. tétel értékét pontszámuk átlagával helyettesítettük, és az így adódó 29 változón az Iskolai Gyerekboldogság Kérdôív pozitív (IGYBpoz) és negatív (IGYBneg) alskálájának azonosításához az Ivens (2007) vizsgálatában leírt utat követtük, és ezeket tartalmuk alapján Pozitív érzelmek, illetve Negatív érzelmek skálának neveztük el. Főfaktoranalízist (vö. Vargha, 2019, 5.3. alfejezet) követően Varimax-forgatást hajtottunk végre az elsô két faktoron. ${ }^{6}$ A forgatott faktorok közül az elsốt a 15 negatív tétel feszítette ki (0,334-0,628 közti súlyokkal), a másodikat pedig a 14 pozitív tétel (0,369-0,621 közti súlyokkal). Bár az ezen tételek pontértékének sima összegezésével definiált két alskála Cronbach-alfa-értéke $(0,863$, illetve 0,855) kiváló belsố konzisztenciát jelzett, a sima kétskálás modellt tesztelô Mplus programmal futtatott - konfirmatív faktoranalízis (CFA; vö. Vargha, 2019, 6. fejezet) nehezen elfogadható, felemás eredményre vezetett. Az abszolút illeszkedési mutatók ugyan jó modellre utaltak (RMSEA = 0,051 <0,06; C95 = [0,048; 0,053] tartalmazza a 0,05-ot; pClose $=0,359>0,05$ n.sz.; SRMR $=0,058<0,08)$, a modell illeszkedése szignifikánsan rossz volt $\left(\chi^{2}=1612,8, \mathrm{f}=376, \mathrm{p}<0,0001\right)$, a takarékossági index meghaladta a 3,5-et $\left(\chi^{2} / \mathrm{f}=4,2\right)$, és a relatív illeszkedési mutatók értéke $(\mathrm{CFI}=0,807$; TLI = 0,792) távol volt a minimálisan elfogadható 0,90-es szinttôl (vö. Vargha, 2019, 6.3. táblázat). Ezt az eredményt a robusztus MLMV-módszerrel ${ }^{7}$ kaptuk, mely saját tapasztalataink szerint a normalitás sérülése esetén a legjobb robusztus ML-alternatíva, s ennél jobbat most sem sikerült kapni sem az MLR, sem az MLM robusztus módszer-

A szerzôk ezúton mondanak köszönetet Kontra Miklósnak és Varga Györgynek, akik a fordítást ellenôrizték és több helyen javították.

Érvényes esetek száma: 1131.

Maximum likelihood modellbecslés robusztus standard hibákkal, valamint átlaggal és varianciával korrigált khi-négyzet tesztstatisztikával (skálaeltolást alkalmazó módszer), vö. http://lavaan.ugent.be/ tutorial/est.html 
rel. Az illeszkedés akkor sem javult, ha bifaktoros modellt adtunk meg, vagy ha egyetlen közös másodrendú faktor alá hoztuk a GYBpoz és a GYBneg skálát.

Ezután a teszt javítása érdekében a CFA-ban - maradva az MLMV módszernél több lépésben mindkét alskálából elhagytuk a legalacsonyabb faktorsúlyú tételeket. Így végül mindkét alskálát 6 tételesre rövidítettük, ami összhangban van azzal a Karl Wuensch által megfogalmazott elvárással, hogy minden faktor tartalmazzon minimum 6 változót. $^{8}$ Ebben a modellben ${ }^{9}$ már minden tétel faktorsúlya meghaladta a 0,50 -et (IGYBpoz: 0,51-0,78; IGYBneg: 0,52-0,71) és az illeszkedési mutatók az illeszkedési statisztika $\left(\chi^{2}=135,0, \mathrm{f}=53, \mathrm{p}<0,0001\right)$ kivételével mind kiváló szintúek voltak (takarékossági index $=2,55$; RMSEA $=0,035$; C95 $=[0,027 ; 0,042]$; pClose $=1 ;$ SRMR = 0,026; CFI $=0,974$; TLI $=0,968)$. A $\chi^{2}$-statisztika szignifikanciájának fố oka az 1000 feletti mintaelemszám, mely az elméleti modelltól való kismértékú eltéréseket feleslegesen túlhangsúlyozza. Megjegyezzük, hogy amikor MLMV helyett az MLR módszert választottuk, az illeszkedési mutatók értékei csak a 3. tizedesben különböztek az MLMV esetén kapottaktól.

Ezzel a tesztrövidítéssel IGYBpoz-ba a 6., 11., 16., 23., 26. és 30., IGYBneg-be pedig a 4., 5., 12., 13., 15. és 25. sorszámú tételek kerültek (vö. Melléklet). Az érvénytelen kérdőívek kiszürése érdekében továbbra is javasoljuk a 16. tétel megismétlését a kérdôívben (kis módosítással, hogy a szó szerinti ismétlés ne okozzon gondot) és a kiértékelésnél e két tétel átlagolását. A rövidített, 13 tételes teszt tehát a tételek sorszámaival megadva: 16., 4., 6., 5., 11., 12., 23., 13., 16. (így módosítva: Kellemesen éreztem magam), 15., 26., 25. (így pontosítva: Fel akartam adni, mindentôl elment a kedvem), 30. Elemzéseinkben az esetenként hiányzó adatok miatt a két alskálát tételeik átlagolásával számítottuk ki, a teszt két alskáláját egyesítô fôskálát (IGYB) pedig IGYBpoz és a pozitívra átfordított IGYBneg átlagaként.

Ezzel a tesztrövidítéssel a skálák Cronbach-alfa-értéke továbbra is kiváló szintû maradt (IGYB: 0,85; IGYBpoz: 0,78; IGYBneg: 0,80). A kapott modellben IGYBpoz és IGYBneg látens faktora 0,715-ös korrelációban volt, ami erôs függésüket és a teszt alapvetốen egydimenziós voltát jelzi. Végül megemlítjük, hogy a teljes és a rövidített teszt azonos IGYBpoz, IGYBneg, IGYB skálái közti korreláció rendre 0,911, 0,906 és 0,943 volt $(\mathrm{N}=1415)$, vagyis a tételek számának csökkentésével nem változott meg a skálák jelentéstartalma.

\section{A Mentális Egészség Teszt Gyermek változata (METGy)}

A mentális egészség feltérképezésére szerkesztett 20 tételes kérdőívet a felnôtt MET-kérdôív (Oláh és mtsai, 2018) gyerekekre igazításával állítottuk össze (lásd melléklet). Ebben a munkában figyelembe vettük általános iskolai tanulók és pedagógusok visszajelzéseit is. A 20 tétel mindegyikénél a vizsgált személynek 6-fokú Likert-skálán kell eldöntenie, hogy az adott állítás mennyire jellemzó rá: 1 - „egyáltalán nem

Vö. core.ecu.edu/psyc/wuenschk/MV/FA/FA-SPSS.pptx

Érvényes értékek száma: $\mathrm{N}=1288$ 
jellemző”, 6 - „teljes mértékben jellemzô”. A 20 tételbôl 19-et vontunk be a METGy öt skálájába, egy (a 9.) pedig egy kontrollként használható Flow tétel.

A MET eredeti változatában (Oláh és mtsai, 2018) Globális jóllétnek nevezett skálát METGy-ben átneveztük sima Jóllét skálának abból a megfontolásból, hogy a kérdôív ezt mérô három tétele (1. Mindennapjaimban érezhetôen több az öröm, mint a bánat, 16. Lelkiállapotom jónak mondható, 20. Mindent összevetve mennyire mondanád magad boldognak?) nem alkalmas a globális jóllét mind a négy - biológiai, pszichológiai, szociális és spirituális - összetevoojének lefedésére. Ez a skála ezekkel a tételekkel inkább tekinthetô a szubjektív jóllét egy mértékének.

A mellékletben minden tétel után feltüntetjük, hogy melyik skálába tartozik (J: Jóllét, S: Savoring, AV: Alkotó-végrehajtó individuális és szociális hatékonyság, Ö: Önreguláció, R: Reziliencia), persze ez a vizsgálati személyeknek kiadott kérdóíven nem szerepelt. Az átfordítandó tételeket mínusz (-) jellel jelöltük (ilyenek az R és egy kivétellel az Ö skála tételei).

Mivel a kérdôív számos állítása nehezebben érthetô, mint az IGYB tételei, a METGy-t csak az 5-8. osztályosokkal töltettük ki. Az elemzésekbôl kihagytuk azokat, akik a 20 tételból 3-nál több kérdésre nem válaszoltak, a megmaradó elemszám N = 707 lett (339 fiú, 365 lány, 3 gyerek neme nem volt megadva).

Elsôként megnéztük a skálák Cronbach-alfa-értékeit (J: 0,789; S: 0,675; AV: 0,708; Ö: 0,396; R: 0,700). Kiderült, hogy Ö esetében az egyetlen nem fordított tétel (13. Érzelmeim, indulataim ritkán vezetnek meggondolatlan tettre) negatív $(-0,11)$ itemmaradék-korrelációval markánsan kilógott az önreguláció skálájából, ezért kihagytuk, amivel a skála Cronbach-alfa-értéke 0,623-ra emelkedett. Bár ez az érték még mindig alacsonyabb a szokásosan elvárt 0,70-es szintnél, már ad némi reményt, hogy az ötskálás modellt tesztelô CFA elfogadható lesz. Úgy is lett, a CFA-ban - szintén az MLMV módszerrel becsült - 5 faktoros modell illeszkedési mutatói az illeszkedési statisztika $\left(\chi^{2}=235,76, \mathrm{f}=124, \mathrm{p}<0,0001\right)$ kivételével mind kiváló szintúek voltak (takarékossági index $=1,90 ;$ RMSEA = 0,037; C95 = (0,030; 0,044); pClose = 0,999; SRMR =0,043; CFI =0,948, TLI =0,935). A $\chi^{2}$-statisztika szignifikanciájának fó oka itt is a nagy mintaelemszám. Ennél jobb illeszkedést nem sikerült kapni sem az MLR, sem az MLM robusztus módszerrel. Az illeszkedés érezhetôen rosszabb volt, amikor egyetlen közös másodrendû faktor alá hoztuk az öt skálát (itt pl. RMSEA = 0,049, CFI $=0,905)$, bifaktoros modell megadása esetén pedig az illeszkedés nem is konvergált.

Megemlítjük, hogy a CFA modelljében megengedtük, hogy a Savoring-skála két tétele (a kérdôívben a 3. és a 11. tétel) esetében a reziduálisok korreláljanak, a nagyon hasonló megfogalmazás miatt.

Az IGYB változóihoz hasonlóan a METGy öt skáláját is a skálába tartozó itemek átlagolásával képeztük (természetesen minden fordított tétel pontértékét visszafordítva a 7 - x transzformációval), a teszt Általános Mentális Egészséget mérô összevont mutatóját (ÁME) pedig az öt skála átlagolásával. 


\section{STATISZTIKAI ELEMZÉSEK ÉS EREDMÉNYEIK}

A két teszt skáláinak alapstatisztikáit az 1. táblázat tartalmazza. ${ }^{10} \mathrm{Ha}$ az IGYBneg átlagát az IGYBpoz skálájára transzformáljuk (az 1-4 értékkészlet figyelembevételével az y = 5 - x lineáris transzformáció alkalmazásával), 3,345-öt kapunk, mely szignifikánsan nagyobb az IGYBpoz átlagánál, 3,086-nél ( $\mathrm{t}=18,443$; f = 1414; $\mathrm{p}<0$,0001). Mivel Cohen $\mathrm{d}=0,474$, a két átlag között szakmailag közepes szintú különbség van. Ez azt jelenti, hogy az IGYBH (és feltehetôen más hasonló tesztek esetén is) a fordított tételeknél a tanulók szívesen jelölnek be az alsó határhoz közeli, kis negativitású, tehát magas pozitivitású értékeket, amit direkt megfogalmazású tételek esetén a magas értékek bejelölésével kevésbé hajlandók megtenni. Vagyis negatív megfogalmazású tételeket alkalmazva könnyebben kapunk magas - és nehezebben kapunk alacsony - értékeket, mint pozitív megfogalmazásúak esetén. Elójelpróbát alkalmazva azt is láthatjuk, hogy a szignifikancián túl $(\mathrm{z}=15,668, \mathrm{p}<0,0001)$ az átfordított IGYBneg-érték az esetek 65,2\%-ában nagyobb, és csak 25,4\%-ában kisebb, mint az IGYBpoz-érték. Ez fontos tanulságul kell, hogy szolgáljon a verbális kérdőívek megszerkesztése során. Megjegyezzük, hogy ez a jelenség fiúknál (Cohen d =0,574) markánsabban jelentkezik, mint lányoknál (Cohen d = 0,395), amit kétszempontos vegyes varianciaanalízis- (VA-) elemzésben az interakció szignifikanciája is jelez $[\mathrm{F}(1 ; 1409)=4,720 ; \mathrm{p}=0,03]$.

$\mathrm{Az}$ 1. táblázat Ferdeség- és Csúcsosság-értékeinek szignifikanciáiból az is kiolvasható, hogy az IGYBH és a METGy skálái egy (AV) kivételével mind erôsen nem normális eloszlásúak, mely körülményt a további statisztikai elemzések során figyelembe kell majd vennünk. A METgy esetében tapasztalható alacsonyabb elemszám (707) oka, hogy ezt a tesztet csak felsố tagozatosoknál vettük fel.

1. táblázat. Az IGYBH és a METGy skáláinak alapstatisztikái

\begin{tabular}{l|l|c|c|c|c}
\hline Változó & $\mathrm{N}$ & Átlag & Szórás & Ferdeség & Csúcsosság \\
\hline IGYBpoz & 1415 & 3,086 & 0,565 & $-0,662 * * *$ & 0,224 \\
\hline IGYBneg & 1415 & 1,655 & 0,547 & $1,027 * * *$ & $1,100^{* * *}$ \\
\hline IGYB & 1415 & 3,215 & 0,489 & $-0,932 * * *$ & $1,080 * * *$ \\
\hline Jóllét & 707 & 4,396 & 1,000 & $-0,589 * * *$ & 0,306 \\
\hline Savoring & 707 & 4,439 & 1,027 & $-0,489 * * *$ & $-0,009$ \\
\hline AV & 707 & 3,662 & 0,863 & 0,140 & 0,204 \\
\hline Önreguláció & 707 & 3,887 & 1,027 & $-0,491^{* * *}$ & 0,152 \\
\hline Reziliencia & 707 & 4,446 & 0,834 & $-0,792^{* * *}$ & $1,039 * * *$ \\
\hline ÁME & 707 & 4,166 & 0,648 & $-0,456^{* * *}$ & $0,959 * * *$ \\
\hline
\end{tabular}

Megjegyzések: *: $\mathrm{p}<0,05$ **: $\mathrm{p}<0,01$ ***: $\mathrm{p}<0,001 ; \mathrm{AV}=$ Alkotó-végrehajtó individuális és szociális hatékonyság, AME = Általános Mentális Egészség

Ezután kiszámítottuk a két teszt skáláin belül, majd a skálák között a páronkénti korrelációkat, a normalitás sérülése miatt a Pearson-féle lineáris korrelációk helyett Spearman-féle rangkorrelációkat alkalmazva (lásd 2. táblázat). 
2. táblázat. Az IGYBH és a METGy skáláinak Spearman-féle rangkorrelációs mátrixa (elemszámok: az IGYBH-n belül $\mathrm{N}=1415$, az összes többi viszonylatban $\mathrm{N}=707$ )

\begin{tabular}{|c|c|c|c|c|c|c|c|c|}
\hline Változó & IGYBneg & IGYB & $\mathrm{J}$ & $\mathrm{S}$ & AV & $\ddot{O}$ & $\mathrm{R}$ & ÁME \\
\hline IGYBpoz & $-0,494 * *$ & $0,871 * *$ & $0,674 * *$ & $0,463 * *$ & $0,412 * *$ & $0,187 * *$ & $0,445^{* *}$ & $0,644 * *$ \\
\hline IGYBneg & & $-0,843 * *$ & $-0,544 * *$ & $-0,248 * *$ & $-0,180 * *$ & $-0,383 * *$ & $-0,552 * *$ & $-0,572 * *$ \\
\hline IGYB & & & $0,697 * *$ & $0,410 * *$ & $0,340 * *$ & $0,321 * *$ & $0,570 * *$ & $0,698 * *$ \\
\hline $\mathrm{J}$ & & & & $0,512 * *$ & $0,395^{* *}$ & $0,220 * *$ & $0,530 * *$ & $0,795^{* *}$ \\
\hline$S$ & & & & & $0,425 * *$ & $0,091 *$ & $0,220 * *$ & $0,679 * *$ \\
\hline $\mathrm{AV}$ & & & & & & $0,076^{*}$ & $0,151 * *$ & $0,583 * *$ \\
\hline Ö & & & & & & & $0,444 * *$ & $0,549 * *$ \\
\hline $\mathrm{R}$ & & & & & & & & $0,670 * *$ \\
\hline
\end{tabular}

Megjegyzések: *:. $\mathrm{p}<0,05 * *: \mathrm{p}<0,01 ; \mathrm{J}=$ Jóllét, $\mathrm{S}=$ Savoring, $\mathrm{AV}=$ Alkotó-végrehajtó individuális és szociális hatékonyság, $\mathrm{O}$ = Önreguláció, $\mathrm{R}$ = Reziliencia, ÁME = Általános Mentális Egészség

\section{A 2. táblázat alapján az alábbi észrevételeket tehetjük.}

1. Az IGYBH-n belül a pozitív és a negatív alskála egyaránt 0,8 feletti korrelációban van az IGYB fôskálával, ami megerôsíti a teszt egydimenziós jellegét. Ugyanakkor a köztük lévô mindössze 0,5 körüli szorosságú - vagyis mindössze $25 \%$ körüli kölcsönös megmagyarázott varianciaarányú - kapcsolat (a kiszámított Pearson-féle $r$ értéke is csak -0,55) arra utal, hogy az egyenes és a fordított tételekból kiszámított skálák nemcsak értékszintjük nagyságában, hanem értelmezésükben is eltérhetnek. Esetünkben nem elég tehát az IGYBH IGYB főskálájára szorítkozni, érdemes az alskálák jelentését külön-külön is megvizsgálni.

2. A METGy skáláin belül az interkorrelációk széles terjedelemben, 0,076-0,530 között szóródnak, ami egyedi jelentésüknek ad teret.

3. A METGy-n belül az ÁME legerôsebben, közel 0,80-as szinten a Jóllét skálával korrelál, így az ÁME elsôdlegesen a jóllét (szubjektív jóllét) szintjérôl informál. Ettôl leginkább különbözô jelentése az Önreguláció és az Alkotó-végrehajtó hatékonyság skálának lehet.

4. Az IGYBH és a METGy skálái közti korrelációk alapján az alábbi következtések fogalmazhatók meg.

a) IGYBpoz-zal mindig erôsebb korrelációban vannak a METGy egyenes megfogalmazású tételekbôl építkezô skálái (Jóllét, Savoring, Alkotó-végrehajtó hatékonyság), mint IGYBneg-gel (pl. az Alkotó-végrehajtó hatékonyság esetében 0,412 vs. $-0,180)$. A fordított tételekból építkezô skálák (Önreguláció, Reziliencia) esetében viszont a helyzet fordított, itt mindig IGYBneg-gel kapcsolatban tapasztalhatunk erôsebb korrelációt (pl. az Önreguláció esetében -0,383 vs. 0,187).

b) A METGy skálái közül a legerôsebb, 0,70-es szintû korrelációt a Jólléttel és az ÁME-vel láthatjuk, ami megerôsíti, hogy az IGYB skála alapvetôen egy szubjektívjóllét-mutató, ahogy a METGy Jóllét skálája is.

A nem és az osztály hatását is megnéztük, s ezzel kapcsolatban az alábbi eredményeket kaptuk.

1. Az IGYBH-ban a fiúk Cronbach-alfája mindhárom skálán alacsonyabb $(0,755$; $0,776 ; 0,831)$, mint a lányoké $(0,804 ; 0,818 ; 0,867)$, a 3. táblázat adataihoz hasonlóan, 
de a skálák nagyságszintje között Mann-Whitney-próbával nem jött ki szignifikáns különbség $(\mathrm{p}>0,05)$.

2. Az esetleges interakciók felderítése céljából a nemmel és az osztállyal robusztus kétszempontos elemzéseket végeztünk (20\%-os trimmelt VA-t és rang-VA-t), és az IGYBneg-gel kapcsolatban kaptunk szignifikáns interakciós hatást (mindkét elemzésnél $\mathrm{p}<0,05$ szinten). Ennek oka, hogy magasabb osztályokban a lányok IGYBneg-szintje fokozatosan nô, és egyre jobban meghaladja a fiúkét (lásd 1. ábra). Ebból eredôen összességében a lányok fölényével a nem hatása is szignifikáns lett (mindkét elemzésnél $\mathrm{p}<0,001$ szinten) és úgyszintén lányoknál az iskolázottság IGYBneg-emelô hatása (Spearman-féle $\mathrm{r}_{\mathrm{s}}=0,161, \mathrm{p}<0,001$ ). Hozzátesszük, hogy ezek a szignifikáns hatások a szakmai értelmezhetôség határán vannak.

3. Ugyanakkor az IGYBpoz és az IGYB a teljes mintán is szignifikáns negatív kapcsolatban van az osztállyal $\left(\mathrm{r}_{\mathrm{s}}=-0,207\right.$, ill. $\left.\mathrm{r}_{\mathrm{S}}=-0,185 ; \mathrm{p}<0,001\right)$, vagyis magasabb osztályokban a tanulók szubjektívjóllét-szintje alacsonyabb. Az osztály hatását IGYBpoz-ra robusztus rang-VA-val vizsgálva szintén erôsen szignifikáns hatást kaptunk, 5,4\%-os közepes szintû rang $\eta^{2}$-tel.

4. A fiúk Cronbach-alfái a METGy-ben is alacsonyabbak, mint a lányoké, minden skála esetében (lásd 3. táblázat). A skálák nagyságszintje tekintetében viszont nem kaptunk szakmailag releváns különbségeket (az átlagokból, rangátlagokból kiszámított Cohen-d egy esetben se haladta meg a 0,20-as szintet), bár a Savoring és az Alkotó-végrehajtó hatékonyság egyaránt szignifikánsan magasabb szintû volt lányoknál, mint fiúknál (Mann-Whitney-próba, p <0,01).

5. AV esetében még szignifikáns osztályhatást is tapasztaltunk (kétszempontos trimmelt VA-ban, illetve rang-VA-ban az osztály hatása egyaránt $\mathrm{p}<0,001$ szinten szignifikáns; vö. 2. ábra), bár a hatás mértéke itt is kicsi $\left(\operatorname{rang} \eta^{2}=0,02\right)$.

\section{IGYBneg: 20\%-os trimmelt átlagok}

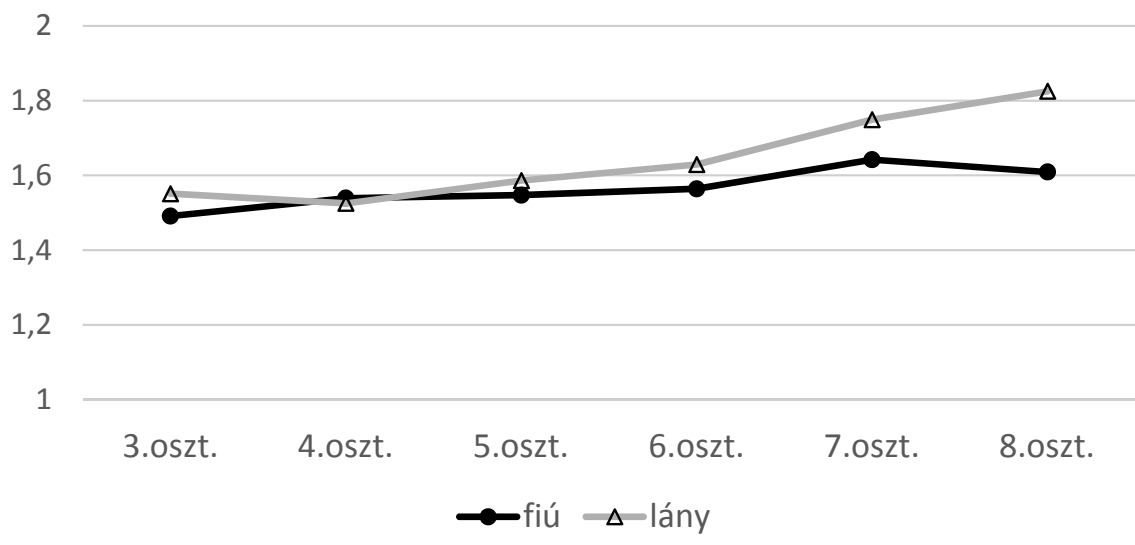

1. ábra. Az IGYBneg skála 20\%-os trimmelt átlagai a nem és az osztály szerinti bontásban 
3. táblázat. A METGy skáláinak Cronbach-alfával mért belsố konzisztenciája fiúknál és lányoknál

\begin{tabular}{|l|l|l|l|l|l|l|}
\hline & J & S & AV & O & R & ÁME \\
\hline Fiúk & 0,783 & 0,648 & 0,704 & 0,600 & 0,644 & 0,803 \\
\hline Lányok & 0,798 & 0,699 & 0,712 & 0,635 & 0,738 & 0,860 \\
\hline
\end{tabular}

Megjegyzés: A skálák teljes neveit illetôen lásd a 2. táblázatot

\section{AV: $20 \%$-os trimmelt átlagok}

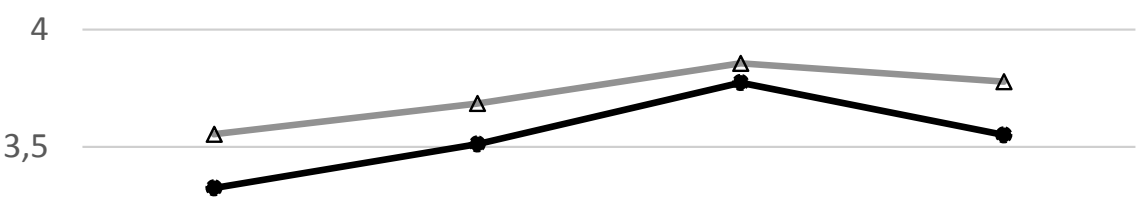

3

2,5

2
5.oszt.
6.oszt.
7.oszt.
8.oszt.

\section{—fiú $\Delta$ lány}

2. ábra. A METGy Alkotó-végrehajtó individuális és szociális hatékonyság (AV) skálájának 20\%-os trimmelt átlagai a nem és az osztály szerinti bontásban

Korreláltattuk még a két teszt skáláit a METGy kérdőív Flow („Ha valami igazán foglalkoztat, azt nehéz helyzetekben is képes vagyok élvezettel és elmélyülten csinálni.") tételének pontszámával is, és a 4. táblázatban látható eredményekre jutottunk. Ezek összhangban vannak a flow és a mentális egészség sokak által igazolt pozitív kapcsolatával (Oláh, 2005). Végül megjegyezzük, hogy vizsgált skálaváltozóink nagyságszintje nem függött attól, hogy a tanuló járt-e boldogságórákra, vagy sem.

Végül az IGYBH és a METGy közti kapcsolat differenciáltabb vizsgálata céljából a két teszt skáláit (alskáláit) korreláltattuk a másik teszt egyes tételeivel, és azonosítottuk közülük a legerôsebben korrelálókat. IGYBpoz-zal a METGy tételei közül legerôsebben az 1. („Mindennapjaimban érezhetôen több az öröm, mint a bánat" = $\mathrm{r}=$ 0,603 ; tau-b =0,481), a 20. („Mindent összevetve mennyire mondanád magad boldognak?”: $\mathrm{r}=0,577$; tau-b = 0,432), illetve a 16. („Lelkiállapotom jónak mondható”: $\mathrm{r}=0,572 ; \mathrm{tau}-\mathrm{b}=$ 0,450) korrelált. Ugyanezt az eredményt kaptuk az IGYBneg-gel kapcsolatban is, némileg gyengébb korrelációkkal. 
4. táblázat. Az IGYBH és a METGy skáláinak korrelációi a METGy kérdôív 9. (Flow) tételének pontszámával $(\mathrm{N}=706)$

\begin{tabular}{|l|c|c|}
\hline Skála & Pearson $\mathrm{r}$ & Kendall tau-b \\
\hline IGYBpoz & $0,317^{* *}$ & $0,246^{* *}$ \\
\hline IGYBneg & $-0,214^{* *}$ & $-0,161^{* *}$ \\
\hline IGYB & $0,296^{* *}$ & $0,231^{* *}$ \\
\hline Jóllét & $0,366^{* *}$ & $0,276^{* *}$ \\
\hline Savoring & $0,369^{* *}$ & $0,296^{* *}$ \\
\hline AV & $0,392^{* *}$ & $0,309^{* *}$ \\
\hline Önreguláció & 0,023 & 0,015 \\
\hline Reziliencia & $0,176^{* *}$ & $0,112^{* *}$ \\
\hline ÁME & $0,387^{* *}$ & $0,288^{* *}$ \\
\hline
\end{tabular}

Megiegyzések: *: $\mathrm{p}<0,05 * *: \mathrm{p}<0,01 ; \mathrm{AV}=$ Alkotó-végrehajtó individuális és szociális hatékonyság, ÁME = Általános Mentális Egészség

A METGy esetében a Jóllét skálával kaptuk a legerôsebb korrelációkat:

- „Jól éreztem magam." ( $\mathrm{r}=0,597$, tau-b = 0,472);

- „Pozitív érzések voltak bennem.” ( $\mathrm{r}=0,556$, tau-b =0,458);

- „Rossz hangulatban voltam.” ( $\mathrm{r}=-0,516$, tau-b = -0,408);

- „Rosszkedvú voltam.” ( $\mathrm{r}=-0,513$, tau-b = -0,389).

Értelmezhető és jelentésükkel összhangban lévô korrelációkat kaptunk még az alkotó-végrehajtó hatékonysággal („Jól dolgoztam”: $\mathrm{r}=0,423$, tau-b =0,337; „Összpontosítottam”: $\mathrm{r}=0,389$, tau-b $=0,314$ ) és az önregulációval („Ideges, feszült voltam”: $\mathrm{r}=-0,423$, tau-b = -0,337; „Mérges voltam”: $\mathrm{r}=-0,318$, tau- $\mathrm{b}=-0,252)$. Mindezen $\mathrm{r}$ és Kendall-féle tau-b korrelációk $\mathrm{p}<0,001$ szinten szignifikánsak voltak.

\section{MEGBESZÉLÉS}

A szubjektív jóllét mérése iskolai környezetben is fontos, magyar nyelvú teszt azonban az általános iskolai korosztály számára nem áll rendelkezésre. A jelen tanulmány célja Ivens (2007) e célra kialakított tesztjének magyarra adaptálása (IGYBH), illetve egy felnôtt magyar mentális egészség teszt (MET) 10-14 éves korosztályra adaptálása (METGy) volt. Az IGYBH célja a szubjektív jóllét mérése iskolai környezetben, a Mentális Egészség Teszt Gyermek változata azonban ennél szélesebb spektrumú, a mentális egészség öt pillérén (jóllét, savoring, alkotó-végrehajtó hatékonyság, önreguláció, reziliencia) nyugvó teszt.

Az elvégzett pszichometriai elemzések (CFA, itemanalízis) alátámasztották mindkét teszt szerkezeti megfelelőségét. Az IGYBH pozitív és negatív érzelmek alskálája (IGYBpoz és IGYBneg) ugyanazt a közös konstruktumot (szubjektív jóllét) feszíti ki, egymással csak mérsékelt, 0,5 körüli korrelációban van, ami egyaránt adódhat önálló jellegükbôl (Watson és Tellegen, 1999), valamint abból, hogy egyenes és fordított állításokra a vizsgált személyek nem egyforma módon válaszolnak. Mindenképpen érdemes új vizsgálatokban különféle változókkal jobban tisztázni az IGYBH két alskálájának jelen- 
tése közti különbségeket. A jelen vizsgálat ehhez azt tette hozzá, hogy eredményeink szerint negatív megfogalmazású tételeket alkalmazva könnyebben kapunk magas, és nehezebben kapunk alacsony értékeket, mint pozitív megfogalmazásúak esetén, különösen fiúknál. A nemi különbség oka talán az, hogy a fiúk nehezebben ismerik be gyengeségeiket, hibáikat, negatív érzelmeiket - ami lehet a neveltetésük következménye is (a fiúkat a lányokkal szemben sokkal inkább arra nevelik, hogy ne fejezzék ki a negatív érzelmeiket, fájdalmaikat). A megfogalmazás formájának jelentôségét tükrözi az is, hogy az Iskolai Gyerekboldogság Kérdôív és a Mentális Egészség Teszt skáláit korreláltatva az azonos megfogalmazású tételekbôl álló skálák esetében szisztematikusan szorosabb kapcsolatokat találtunk, mint az ellentétes megfogalmazású tételekból álló skálák esetében (lásd 2. táblázat elsố két sora).

Emellett lányoknál fokozottabb az IGYBneg szintjének növekedése 3-8. osztály között, mint fiúknál (lásd 1. ábra), miközben ezzel összhangban az IGYBpoz szintje mindkét nemnél hasonló mértékben csökken. Más szavakkal: magyar iskolákban a tanulók közérzete, szubjektív jólléte az általános iskola magasabb osztályaiban általában alacsonyabb, mint alsóbb osztályokban, ami talán a magasabb osztályokban egyre nehezedô tanulmányi követelményeknek köszönhető. Finn tanulóknál hasonló eredményeket kapott Uusitalo-Malmivaara (2014). Elképzelhető, hogy lányok erre érzékenyebbek, amit a szociális elvárásoknak kevésbé kitett, negatív megfogalmazású tételekre adott válaszok hitelesebben tükröznek. Persze lehet, hogy itt egyszerúen arról van szó, hogy ahogy a gyerekek nônek, érnek, úgy tudatosítják egyre inkább az élet nehézségeit és a felnôtt élet felelôsségével járó terheket. Vagyis a 10 éves gyerekek még életkorukból és kevesebb felelősségükból fakadóan gondtalanabbak, boldogabbak, mint idôsebb társaik.

A vizsgált tesztek validitását részben igazolják a teszttételek tartalmai (felszíni/face validitás), a két teszt skálái közti korrelációk (leginkább a szubjektív jóllét jelentésú IGYB és a Jóllét skála között; vö. 2. táblázat), valamint a flow-val kapott szakmailag is értékelhetố szintû korrelációk (vö. 4. táblázat), ahol a szubjektív jóllét szintje mellett fontos szerepet kapnak a mentális egészség más összetevôi is (különösen az alkotó-végrehajtó hatékonyság és a savoring). A két teszt alskáláinak jelentését megerôsítették a másik teszt tételeivel kiszámított korrelációk is.

A METGy-n belül az érzelmi és indulati kontroll sikerességét jelzô Önreguláció skála meglehetôsen önálló pillérnek tûnik. Megemlítjük még, hogy Vargha, Korényi, Pomsár és Váits (2019) középiskolásokkal végzett vizsgálatában ( $\mathrm{N}=127)$ az érzelmi IQ szignifikáns 0,25 körüli korrelációban volt az IGYBpoz és IGYB, illetve szignifikáns -0,20 körüli korrelációban az IGYBneg skálával, továbbá szintén pozitívan korrelált a METGy-ben a Jólléttel $(r=0,22)$ és a Rezilienciával $(r=0,19)$. Természetesen a METGy öt skálájának teljes tisztázásához még további vizsgálatokra van szükség, ahogy az IGYBH iskolai hasznosíthatóságát illetốen is. Más kultúrákban ilyen jellegú vizsgálatokról számolt be például Allodi (2009), Navarro, Ruiz-Oliva, Larrañaga és Yubero (2013), illetve Wang és Wang (2015).

Emellett egy Magyarországon folytatott kutatás is megerősítette a két teszt validitását (Török, Bene-Kovács, Gôbel és Vargha, 2019), melynek keretében a Kodály-koncepció használatának hatását vizsgáltuk a mentális egészségre és a szubjektív jóllétre 5. és 6. osztályos általános iskolás diákoknál. 224 tanulótól gyújtött adatok alapján a 
Kodály-koncepciós iskolában tanulók szignifikánsan jobb alkotó-végrehajtó hatékonysággal rendelkeztek $[\mathrm{F}(2 ; 221)=6,900 ; \mathrm{p}=0,0012]$, mint az általános tanterv szerint tanuló diákok, illetve a sporttagozatos osztály tagjai. A vizsgálatban hangulatgörbék ábrázolását is kértük a gyermekektôl, ami megerôsítette a kvantitatív elemzések érvényességét. Azok a tanulók, akik az iskolában és otthon is jól érezték magukat, szignifikánsan jobb eredményt értek el az IGYBH és a METGy skáláin (az Önregulációt kivéve).

\section{KÖSZÖNETNYILVÁNÍTÁS}

A szerzôk ezúton mondanak köszönetet a vizsgálatokban való részvételért és az adatok rögzítéséért Egyházi Zsófia, Kispál Sára, Korényi Zsófia, Nagy Gabriella, Pomsár Zsófia, Sipos Adrienn, Váits Petra KRE-s hallgatóknak, valamint a KRE BTK Benda Kálmán Szakkollégium Pszichológiai Múhelye minden hallgatójának. A cikkben említett kutatásokat a Károli Gáspár Református Egyetem (20643B800/2018 számú kutatói pályázat) és az NKFI támogatta (NKFI-6, 116965 számú pályázat).

\section{IRODALOM}

Allodi, M. W. (2009). Goals and values in school: a model developed for describing, evaluating and changing the social climate of learning environments. Social Psychology of Education, 13(2), 207-235.

Block, J., \& Kremen, A. M. (1996). IQ and ego-resiliency: conceptual and empirical connections and separateness. Journal of Personality and Social Psychology, 70(2), 349-371.

Campbell-Sills, L., \& Stein, M. (2007). Psychometric analysis and refinement of the Connor-Davidson Resilience Scale (CD-RISC): Validation of a 10-item measure of resilience. Journal of Traumatic Stress, 20(6), 1019-1028.

Connor, K. M., \& Davidson, J. R. (2003). Development of a new resilience scale: The ConnorDavidson resilience scale (CD-RISC). Depression and Anxiety, 18(2), 76-82.

Diener, E. (1984). Subjective well-being. Psychological Bulletin, 95(3), 542-575.

Diener, E., \& Chan, M. Y. (2011). Happy people live longer: Subjective well-being contributes to health and longevity. Applied Psychology: Health and Well-Being, 3(1), 1-43.

Diener, E., Emmons, R. A., Larsen, R. J., \& Griffin, S. (1985). The Satisfaction With Life Scale. Journal of Personality Assessment, 49(1), 71-75.

Fredrickson, B. L., \& Branigan, C. (2005). Positive emotions broaden the scope of attention and thought action repertoires. Cognition and Emotion, 19(3), 313-332.

Hauser, D. J., Preston, S. D., \& Stansfield, R. B. (2014). Altruism in the wild: When affiliative motives to help positive people overtake empathic motives to help the distressed. Journal of Experimental Psychology: General, 143(3), 1295.

Ivens, J. (2007). The Development of a Happiness Measure for Schoolchildren. Educational Psychology in Practice, 23(3), 221-239.

Láng, A. (2019). A serdülôkori pszichológiai jóllét multidimenzionális mérôeszköze: Az EPOCH kérdôív magyar változatának (EPOCH-H) pszichometriai jellemzôi. Mentálhigiéné és Pszichoszomatika, 20(1), 12-34. 
Laurent, J., Catanzaro, S. J., Joiner, T. E., Rudolph, K. D., Potter, K. I., Lambert, S., et al. (1999). A measure of positive and negative affect for children: Scale development and preliminary validation. Psychological Assessment, 11(3), 326-338.

Myers, D. G. (2000). The funds, friends, and faith of happy people. American Psychologist, 55(1), 56.

Navarro, R., Ruiz-Oliva, R., Larrañaga, E., \& Yubero, S. (2013). The Impact of Cyberbullying and Social Bullying on Optimism, Global and School-Related Happiness and Life Satisfaction Among 10-12-year-old Schoolchildren. Applied Research in Quality of Life, 10(1), 15-36.

Oláh, A. (2005). Érzelmek, megküzdés és optimális élmény. Budapest: Trefort Kiadó.

Oláh, A. \& Kapitány-Fövény, M. (2012): A pozitív pszichológia tíz éve. Magyar Pszichológiai Szemle, 67(1), 19-45.

Oláh, A., Nagy, H., Magyaródi, T., Török, R., \& Vargha, A. (2018). Egy új mentális egészséget mérô kérdôív, a MET kidolgozása. In Lippai Edit (szerk.), Változás az állandóságban. A Magyar Pszichológiai Társaság XXVII. Országos Tudományos Nagygyúlése. Kivonatkötet. Budapest: Magyar Pszichológiai Társaság, 80-81.

Reinhardt, M. (2009). Miért hasznosak a pozitív érzelmek iskolai környezetben? Iskolakultúra, 19(9), 24-46.

Roeser, R. W., Van der Wolf, K., \& Strobel, K. R. (2001). On the relation between social-emotional and school functioning during early adolescence: Preliminary findings from Dutch and American samples. Journal of School Psychology, 39(2), 111-139.

Smith, B. W., Dalen, J., Wiggins, K., Tooley, E., Christopher, P., \& Bernard, J. (2008): The Brief Resilience Scale: Assessing the Ability to Bounce Back. International Journal of Behavioral Medicine, 15, 194-200.

Southwick, S. M., \& Charney, D. S. (2018). Resilience: The science of mastering life's greatest challenges. New York: Cambridge University Press.

Southwick, S. M., Bonanno, G. A., Masten, A. S., Panter-Brick, C., \& Yehuda, R. (2014). Resilience definitions, theory, and challenges: interdisciplinary perspectives. European Journal of Psychotraumatology, 5(1), 25338.

Szabó, A. (2019). Validity of the Hungarian Version of the Subjective Happiness Scale (SHS-HU). Mentálhigiéné és Pszichoszomatika, 20(1), 180-201.

Szondy, M., Martos, T., Szabó-Bartha, A. \& Pünkösty, M. (2014). A Rövidített Pozitív Élmények Feldolgozási Módjai Skála magyar változatának reliabilitás- és validitásvizsgálata. Mentálhigiéné és Pszichoszomatika, 15(3), 305-316.

Uusitalo-Malmivaara, L. (2014). Happiness Decreases during Early Adolescence - A Study on 12- and 15-Year-Old Finnish Students. Psychology, 5(6), 541-555.

Török, R., Bene-Kovács, B., Gốbel, O. \& Vargha, A. (2019). A zene és a sport jótékony hatásai az általános iskolás diákok jóllétére. Poszter a Magyar Pszichológiai Társaság XXVIII. Országos Tudományos Nagygyúlésén. Debrecen, 2019. május 30. - június 1.

Vargha, A. (2016). A ROPstat statisztikai programcsomag. Statisztikai Szemle, 94(11-12), $1165-1192$.

Vargha, A. (2019). Többváltozós statisztika dióhéjban: változó-orientált módszerek. Budapest: Pólya Kiadó.

Vargha, A., Diósi, K., Pásztor, A., Ódor, V. \& Csengôdi, M. (2018). A MET kapcsolata szociodemográfiai változókkal. In Lippai Edit (szerk.), Változás az állandóságban. A Magyar Pszichológiai Társaság XXVII. Országos Tudományos Nagygyúlése. Kivonatkötet. Budapest: Magyar Pszichológiai Társaság. 81.

Vargha, A., Korényi, Zs., Pomsár, Zs. \& Váits, P. (2019). Boldogságmérés 5-8. osztályban. In Lippai Edit (szerk.), Összetart a sokszinúség. A Magyar Pszichológiai Társaság XXVIII. Országos Tudományos Nagygyülése. Kivonatkötet. Budapest: Magyar Pszichológiai Társaság. 139. 
Veenhoven, R. (2008). Healthy happiness: Effects of happiness on physical health and the consequences for preventive health care. Journal of Happiness Studies, 9(3), 449-469.

Wang, F., \& Wang, D. (2015). Place, Geographical Context and Subjective Well-being: State of Art and Future Directions. In D. Wang, S. He (Eds), Mobility, Sociability and Well-being of Urban Living (pp. 189-230). Berlin, Heidelberg: Springer.

Watson, D., \& Tellegen, A. (1999). Issues in dimensional structure of affect-effects of descriptors, measurement error, and response formats: Comment on Russell and Carroll. Psychological Bulletin, 125, 601-610.

Zelenski, J. M., Murphy, S. A., \& Jenkins, D. A. (2008). The happy-productive worker thesis revisited. Journal of Happiness Studies, 9(4), 521-537. 


\section{MELLÉKLET}

\section{Iskolai Gyerekboldogság Kérdôiv (IGYBH)}

A következố állitások arról szólnak, hogy a múlt héten hogyan érezted magad az iskolában. Legyél olyan ôszinte, amennyire csak tudsz, és jelezd minden állításnál a megfeleló oszlopban való bejelöléssel (X), hogy az rád milyen mértékben volt jellemzô a múlt héten!

\begin{tabular}{|l|l|l|l|l|}
\hline Az elmúlt héten az iskolában & $\begin{array}{c}\text { Nagyon } \\
\text { nem jellemzó }\end{array}$ & $\begin{array}{c}\text { Nem } \\
\text { jellemzó }\end{array}$ & $\begin{array}{c}\text { Kicsit } \\
\text { jellemzó }\end{array}$ & $\begin{array}{c}\text { Nagyon } \\
\text { jellemzó }\end{array}$ \\
\hline 1. Tele voltam energiával & & & & \\
\hline 2. Ideges, feszült voltam & & & & \\
\hline 3. Akartam iskolába jönni & & & & \\
\hline 4. Rosszkedvú voltam & & & & \\
\hline 5. Szomorú voltam & & & & \\
\hline $\begin{array}{l}\text { 6. Nyugodtnak, lazának éreztem } \\
\text { magam }\end{array}$ & & & & \\
\hline 7. Úgy éreztem, beteg vagyok & & & & \\
\hline $\begin{array}{l}\text { 8. Úgy éreztem, hogy az iskola } \\
\text { biztonságos hely }\end{array}$ & & & & \\
\hline 9. Összpontosítottam & & & & \\
\hline 10. Gyengének éreztem magam & & & & \\
\hline 11. Pozitív érzések voltak bennem & & & & \\
\hline 12. Mérges voltam & & & & \\
\hline 13. Sírni akartam & & & & \\
\hline 14. Mindenkivel jól kijöttem & & & & \\
\hline 15. Rossz hangulatban voltam & & & & \\
\hline 16. Jól éreztem magam & & & & \\
\hline 17. Fáradt voltam & & & & \\
\hline 18. Nyugodtnak éreztem magam & & & & \\
\hline 19. Élveztem a munkát & & & & \\
\hline 20. Sajnáltam magam & & & & \\
\hline 21. Jól éreztem magam & & & & \\
\hline 22. Zavart voltam & & & & \\
\hline 23. Magabiztos voltam & & & & \\
\hline 24. Indulatos voltam & & & & \\
\hline 25. Fel akartam adni & & & & \\
\hline 26. Úgy éreztem, teljesen éber vagyok & & & & \\
\hline 27. Fejfájásaim voltak & & & & \\
\hline 28. Jól dolgoztam & & & & \\
\hline 29. Rémült voltam & & & & \\
\hline 30. Jól éreztem magam mások & & & & \\
\hline
\end{tabular}




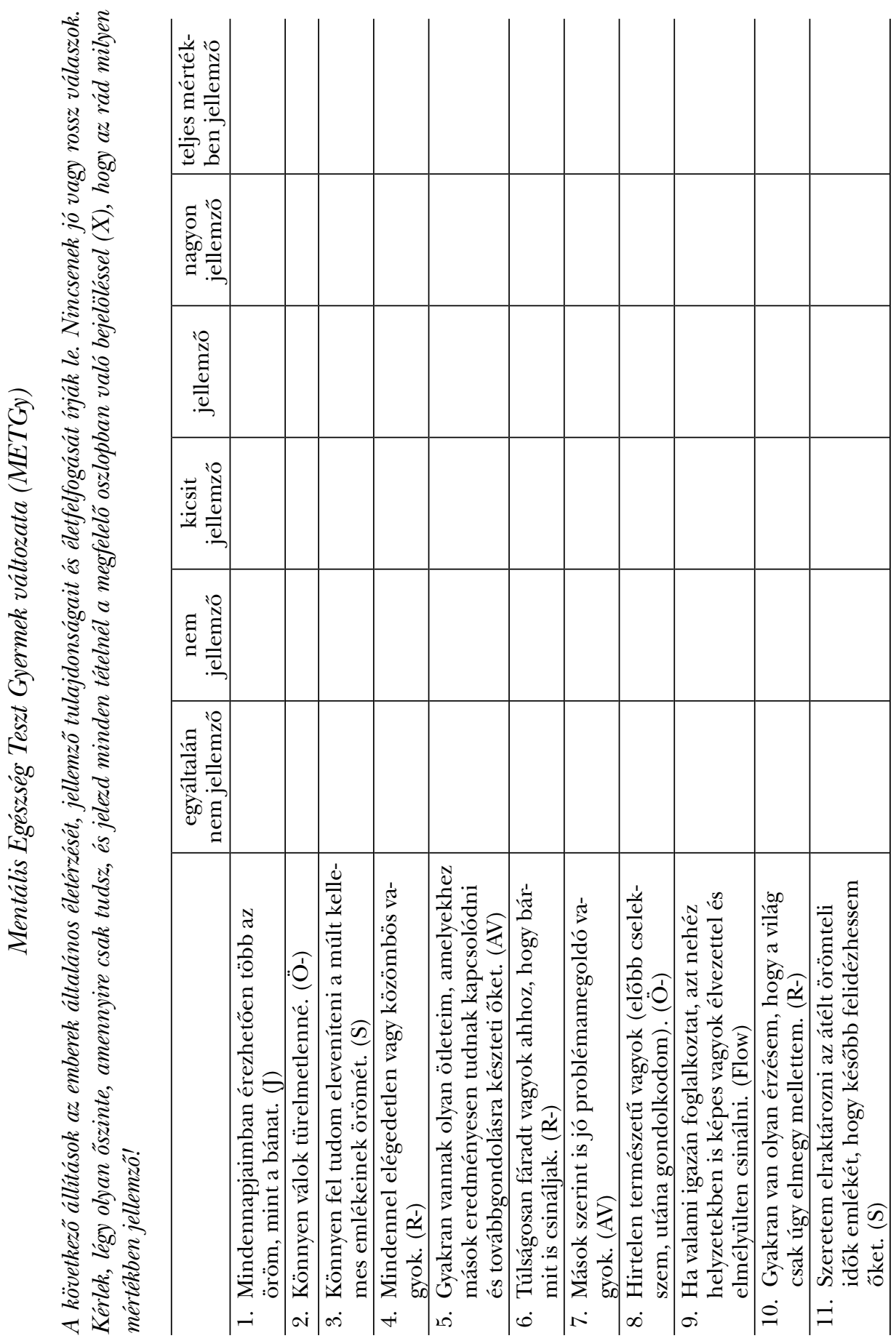




\begin{tabular}{|c|c|c|c|c|c|c|c|c|c|}
\hline 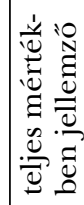 & & & & & & & & & \\
\hline 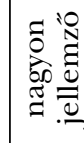 & & & & & & & & & \\
\hline 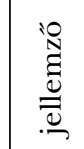 & & & & & & & & & \\
\hline 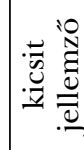 & & & & & & & & & \\
\hline 岧 & & & & & & & & & \\
\hline 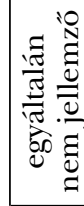 & & & & & & & & & \\
\hline & 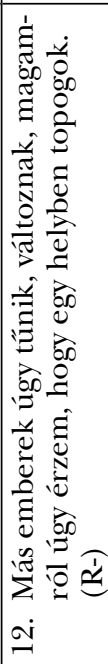 & 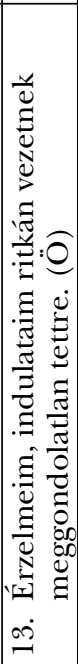 & 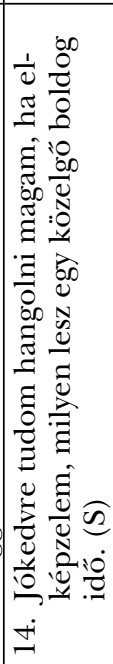 & 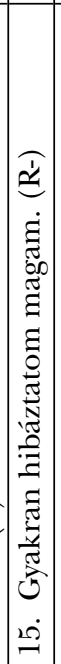 & 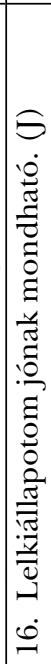 & 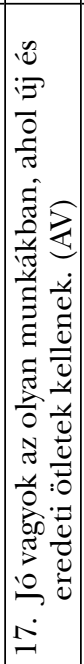 & 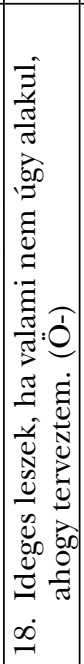 & 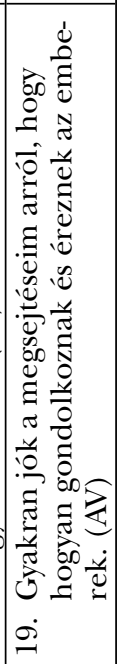 & 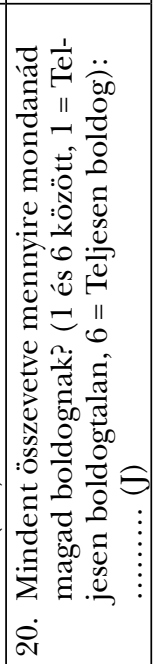 \\
\hline
\end{tabular}




\section{MEASURING SCHOOL HAPPYNESS}

\section{VARGHA, ANDRÁS - TÖRÖK, REGINA - DIÓSI, KAROLA - OLÁH, ATTILA}

Subjective well-being (SWB) and mental health have been studied amongst adults using a variety of selfreported methods. However, there are available relatively few tests of $S W B$ for children. Measuring $S W B$ is also important in the school environment, but there is no valid and reliable Hungarian scale for elementary schoolchildren. The aim of the study presented in this paper was to adapt the School Children's Happiness Inventory (Ivens, 2007) to Hungarian, and to adapt the Mental Health Test developed for adults and based on five pillars (well-being, savoring, creative-executive effectiveness, self-regulation and resilience) for schoolchildren aged 10 to 14. Above the age of 10, the psychometric properties of both tests confirmed their structural reliability and supported their validity. An interesting result is that SWB is in a negative relationship with age among school children .

Keywords: happiness tests, subjective well-being, mental health, SCHI

A cikk a Creative Commons Attribution 4.0 International License (https://creativecommons. org/licenses/by/4.0) feltételei szerint publikált Open Access közlemény, melynek szellemében a cikk bármilyen médiumban szabadon felhasználható, megosztható és újraközölhetô, feltéve, hogy az eredeti szerzó és a közlés helye, illetve a CC License linkje és az esetlegesen végrehajtott módosítások feltüntetésre kerülnek. (SID_1) 